\title{
PENGEMBANGAN MODEL QFD BERBASIS FUZZY KANO UNTUK JASA LAYANAN TRANSPORTASI BAGI DISABILITAS
}

\author{
Prihono $^{1)}$ dan Yunia Dwie Nurcahyanie ${ }^{1)}$ \\ 1) Program Studi Teknik Industri; Fakultas Teknologi Industri \\ Universitas PGRI Adi Buana Surabaya \\ e-mail:mr.riho@gmail.com
}

\begin{abstract}
Abstrak
Karakteristik industri jasa dengan industri manufaktur berbeda. Penelitian ini akan mengembangkan model QFD (Quality Function Deployment) dimana akan dikembangkan untuk jasa layanan industri transportasi umum. Untuk menggambarkan implementasi model, akan diuji untuk transportasi bagi penyandang cacat. Hal ini karena setiap warga negara berhak untuk mendapatkan layanan transportasi umum, termasuk penyandang cacat. Penelitian dimulai dengan identifikasi Voice of Customer $(\mathrm{VoC})$ dengan menggunakan metode Kano, yaitu dengan kuesioner fungsional dan disfungsional ke responden. Langkah berikutnya adalah menggunakan metode Fuzzy untuk mengurangi jawaban yang subjektiv dari responden. Setiap atribut kemudian diklasifikasikan ke dalam kategori Kano: must be, one dimensional, attractive, dan indifferent. Untuk merancang sistem layanan, digunakanlah QFD . Berdasarkan hasil analisis QFD, ada sebelas kriteria untuk kebutuhan layanan yang dari VoC dan 21 atribut respon teknik yang digunakan untuk merancang sistem pelayanan. Selain itu, berdasarkan perhitungan VoC untuk bus untuk penumpang cacat, nilai tertinggi adalah atribut keamanan. Untuk itu, diperlukan adanya pusat informasi di halte-halte bus dan terminal-terminal
\end{abstract}

Kata kunci: Disabilitas, Fuzzy, KANO, QFD, Transportasi Umum

\begin{abstract}
Characteristics of the service industry with the manufacturing industry are different. This study development a model of QFD which will be developed for public transportation services industry. To illustrate the implementation of the model, it will be tested for the transportation of persons with disabilities. This is because every citizen is entitled to services, including persons with disabilities. The study started with the identification of Voice of Customer (VoC) by employing the Kano method, that is, by administering the functional and dysfunctional questionnaire to the respondent. The next step was to use the Fuzzy method to reduce subjectivity of the respondents' answer. Each of the attributes was then classified into the Kano categories: must be, one dimensional, attractive, and indifferent. To design the service system, the QFD was employed. Based on the result of QFD analyses, there were eleven criteria for the service needs of VoC and 21 attributes of technique responses used to design the service system. In addition, based on calculation of VoC for disable bus passengers, the highest score was of the security attribute. For that purpose, was needed to be done was to assign information center on bus stops and terminals.
\end{abstract}

Keywords: Disabilities, Fuzzy, KANO, QFD, Public Transportation

\section{PENDAHULUAN}

Usaha untuk meningkatkan kualitas layanan perusahaan dalam rangka memenuhi kepuasan konsumen merupakan salah satu usaha yang sangat penting. Karena dalam banyak hal, konsumenlah yang membuat keputusan untuk apa layanan perusahaan tersebut untuk dikomsumsi dan seberapa mampu layanan perusahaan tersebut mencapai tujuan yang diharapkannya. Oleh karena itu diperlukan suatu cara atau model yang bisa menerjemahkan kebutuhan dan keinginan konsumen. 
Salah satu metode pengukuran
kualitas yang bisa menerjemahkan
kebutuhan dan keinginan konsumen adalah
metode QFD (quality function deployment).
QFD adalah metode perencanaan dan
pengembangan produk yang terstruktur yang
mengharuskan tim pengembangan produk
untuk menentukan secara jelas keinginan
dan kebutuhan konsumen dan melakukan
evaluasi secara sistematis tentang kemampuannya dalam menghasilkan produk untuk memuaskan konsumen. Fokus utama QFD pada pemenuhan harapan konsumen yang didapat dari identitifikasi pelanggan yang kemudian diterjemahkan dalam perbaikan atau penyesuaian karakter atau atribut (Prihono, 2012).

QFD sudah banyak dikembangkan untuk pengukuran kualitas, sebagaimana yang dilakukan Suhartini (2011) yang menggabungkan QFD dengan fuzzy, dimana diujikan pada pemilihan supplier dan hasil yang didapatkan bahwa fuzzy mampu mengabungkan beragam pilihan dalam merespon kebutuhan konsumen sehingga QFD menjadi lebih baik. Dengan menggunakan teori fuzzy, analisis QFD bisa lebih kuantitatif dalam mengevaluasi keputusan yang bersifat subyektif. Hal yang sama terkait fuzzy menurut Prihono (2012), dimana teori fuzzy menawarkan konsep dalam suatu frame work untuk menampung adanya informasi yang tidak pasti maupun samar (imprecise). Penggunaan terori fuzzy set memberi flesibilitas untuk menampung ketidakpastian akibat samarnya informasi yang dimiliki maupun unsure preferensi yang subyektif yang dapat digunakan dalam pengambilan keputusan.

Kano merupakan metode yang bertujuan untuk mengkategorikan atributatribut dari produk maupun jasa berdasarkan seberapa baik produk atau jasa tersebut mampu memuaskan kebutuhan konsumen. Model Kano menggolongkan 3 (tiga) tipe pemenuhan kepuasan konsumen yaitu MustBe, One Dimensional, dan Attractive (Prihono, 2012). Kombinasi model Kano dengan metode lainnya juga sudah dilakukan. Hanoum at al (2009) telah menggabungkan dan membandingkan model Kano dengan IPA (Importance Performance Analysis). Dimana kasus yang diteliti adalah kualitas penyedia layanan kesehatan. IPA (Importance Performance Analysis) mampu menggolongkan dan memprioritaskan atribut-atribut kualitas dengan mudah, namun tidak bisa menjabarkan suatu atribut tergolong kebutuhan basic atau attractive sebagaimana Kano.

QFD berbasis fuzzy-Kano sudah digunakan di industri manufaktur seperti yang yang sudah dikem-bangkan oleh Lee $e t$ al. (2007). Dimana hasil dari penggabungan fuzzy-KANO mampu memperbaiki hasil output dari QFD. Tetapi hal ini belum digunakan di bidang industri jasa yang mempunyai karakteristik berbeda jika dibandingkan dengan industri manufaktur. Hal ini yang merupakan gap penelitian yang akan diteliti dalam riset ini.

Perbedaan karakteristik industri jasa dengan industri manufaktur mengharuskan kita tidak bisa menyamakan penanggannya. Begitu juga dalam pengukuran kualitas layanan yang dihasilkannya. Dimana industri jasa pada dasarnya bersifat intangible (tidak berwujud fisik) dan tidak menghasilkan kepemilikan sesuatu (Kotler, 2000). Sebagaimana telah dijelaskan dalam latar belakang bahwa pengukuran kualitas layanan terhadap produk sudah banyak dikembangkan. Namun untuk layanan terhadap industri jasa khususnya industri jasa transportasi umum, penggunaan QFD berbasis fuzzy-KANO belum ada. Penelitian ini akan mengembangkan model Lee et al. (2008) yang akan dikembangkan untuk industri jasa transportasi umum.

\section{METODE}

Proses pengumpulan data dilakukan dengan cara: kuisioner yang disebarkan kepada pengguna bus penumpang umum (penyandang cacat) dan masyarakat penyandang disabilitas yang sudah menggunakan jasa layanan kendaraan umum, disebar dengan variasi usia, latar belakang pendidikan, jenis kelamin dan pekerjaan yang berbeda. Kuisioner ini dirancang dengan menggunakan standar kuisioner model Kano yaitu mencari pemetaan jawaban like, must be, neutral, like with, dislike. Selanjutnya dilakukan observasi pengamatan terhadap pelayanan penumpang bis kota di Surabaya. Sebagai populasi dalam penelitian ini adalah masyarakat penyandang cacat yang mempunyai pengalaman terhadap bis kota di wilayah Surabaya, utamanya untuk jalur dari 
terminal Bungurasih ke terminal Jembatan Merah, dan sebaliknya. Untuk menentukan jumlah sampel penelitian, maka digunakan perhitungan Bernoulli. Ukuran sample minimum dalam penelitian ini dapat dihitung sebagai berikut:

$$
N \geq \frac{\mathrm{Z} \alpha / 2^{2} \times \mathrm{p} \times \mathrm{q}}{\mathrm{e}^{2}}
$$

dimana :

$$
\begin{aligned}
\mathrm{N}= & \text { jumlah responden minimal } \\
& \text { yang dapat diambil. } \\
Z^{\alpha} / 2= & \text { tingkat level kepercayaan } \\
& \text { yang akan digunakan }(95 \%) . \\
\mathrm{p}= & \text { proporsi jumlah responden } \\
& \text { yang mengisi dengan benar } \\
& \text { pada kuesioner penda- } \\
& \text { huluan. } \\
= & \text { proporsi jumlah responden } \\
& \text { yang mengisi dengan salah } \\
& \text { pada kuesioner penda- } \\
& \text { huluan. } \\
= & \text { tingkat error yang diijinkan. } \\
\mathrm{e}= & \text { taraf signifikasi. }
\end{aligned}
$$

Hasil penyebaran kuesioner awal dalam penelitian ini bahwa 30 kuesioner yang disebarkan terdapat 1 buah kuesioner yang dianggap salah, karena responden tidak memberikan jawabannya pada beberapa pertanyaan. Dengan menggunakan tingkat kepercayaan sebesar $95 \%$ dan tingkat kesalahan sebesar $5 \%$, maka kecukupan data untuk penelitian ini yaitu:

$$
N \geq \frac{1.96^{2} \times 0.98 \times 0.02}{0.05^{2}}=30.12
$$

Untuk menghindari kekurangan data akibat kesalahan pengisian, maka disebarkan kuesioner sebesar 50 orang.

Model Kano digunakan untuk mencari tingkat kepuasan pengguna. Di dalam model ini, Kano mencari kepuasan pengguna

\section{HASIL DAN PEMBAHASAN \\ Analisis Kebutuhan Konsumen dengan Model Fuzzy-Kano}

Dari perhitungan Fuzzy KANO, diperoleh pemetaan kategori masing-masing atribut (Tabel 2). dengan requirement produk dengan beberapa kategori:

1. Must Be Requirements: Jika kriteria ini tidak bisa dipenuhi, maka kriteria ini tidak akan mampu meningkatkan kepuasan pengguna, sebaliknya jika kriteria ini terpenuhi maka akan dapat meningkatkan kepuasan pengguna.

2. One Dimensional Requirements: dengan memenuhi kriteria ini, maka kepuasan pengguna akan menjadi lebih proposional, semakin tinggi tingkat pemenuhan requirement ini maka semakin tinggi tingkat kepuasan pengguna dan sebaliknya.

3. Attractive requirements: kriteria produk dimana yang memiliki pengaruh terbesar bagaimana sebuah atribut bisa meningkatkan kepuasan pengguna, saat atribut ini diberikan pada produk. Kriteria ini menjadi yang diharapkan oleh pengguna, namun jika kriteria ini tidak mampu dipenuhi maka tidak ada kekecewaan dari pengguna.

Dengan menerapkan fungsi keanggotaan fuzzy sebagaimana terlihat pada Gambar 1, diharapkan keberadaan kriteriakriteria yang memiliki jumlah indikator pada kategori yang bersebelahan juga dapat memberikan pengaruh pada penyusunan indek. Formulasinya adalah sebagai berikut:

Dimana :

$$
\begin{aligned}
& \mathrm{RA}_{\mathrm{w}, \mathrm{i}}=\sum \mathrm{K}_{\mathrm{w}, \mathrm{i}} \\
& \mathrm{RR}_{\mathrm{w}, \mathrm{i}}=\sum \mathrm{K}_{\mathrm{w}, \mathrm{i}} / \mathrm{P}_{\mathrm{w}}
\end{aligned}
$$

$\mathrm{RA}_{\mathrm{w}, \mathrm{i}}=$ index rangking absolut dengan kategori i pada kriteria $\mathrm{w}$

$\mathrm{RR}_{\mathrm{w}, \mathrm{i}}=$ index rangking relatif dengan kategori i pada kriteria $\mathrm{w}$

$\mathrm{K}_{\mathrm{w}, \mathrm{i}}=$ hasil fungsi keanggotaan kategori i pada tiap skala

$\mathrm{P}_{\mathrm{w}}=$ jumlah nilai seluruhnya pada wilayah $\mathrm{W}$ 


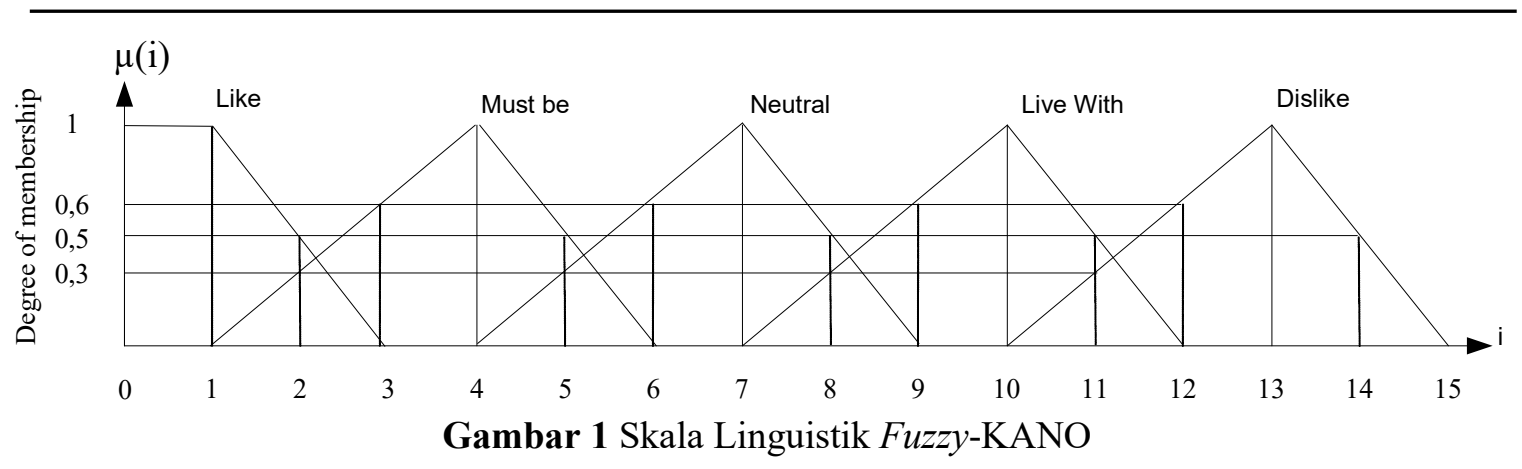

Tabel 1 Fungsi Keanggotaan Kuesioner Model Fuzzy KANO

\begin{tabular}{|c|c|c|c|c|c|c|c|c|c|c|c|c|c|c|c|}
\hline \multirow{2}{*}{ CR1 } & \multicolumn{3}{|c|}{ Like } & \multicolumn{3}{|c|}{ Must be } & \multicolumn{3}{|c|}{ Neutral } & \multicolumn{3}{|c|}{ Live With } & \multicolumn{3}{|c|}{ Dislike } \\
\hline & $\mathrm{H}$ & $\mathrm{M}$ & $\mathrm{L}$ & $\mathrm{H}$ & $\mathrm{M}$ & $\mathrm{L}$ & $\mathrm{H}$ & $\mathrm{M}$ & $\mathrm{L}$ & $\mathrm{H}$ & $\mathrm{M}$ & $\mathrm{L}$ & $\mathrm{H}$ & $\mathrm{M}$ & $\mathrm{L}$ \\
\hline Functional Ques & 1 & 0,8 & 0,6 & 1 & 0,8 & 0,6 & 1 & 0,8 & 0,6 & 1 & 0,8 & 0,6 & 1 & 0,8 & 0,6 \\
\hline Dysfunctional Questionnaire & 1 & 0,8 & 0,6 & 1 & 0,8 & 0,6 & 1 & 0,8 & 0,6 & 1 & 0,8 & 0,6 & 1 & 0,8 & 0,6 \\
\hline
\end{tabular}

Tabel 2 Penilaian Fuzzy Kano untuk bus penyandang cacat.

\begin{tabular}{lcccccccc}
\hline \multicolumn{1}{c}{ CUST. REQ. } & A & O & M & I & R & FUZZY-KANO & KANO Tradisional \\
\hline Keamanan & 11 & 0 & 0 & 34 & 3 & A & I \\
Ongkos/Tarip & 10 & 0 & 4 & 33 & 3 & A & I \\
Tempat Duduk & 7 & 0 & 2 & 37 & 3 & A & I \\
Kebersihan & 1 & 2 & 8 & 34 & 4 & M & I \\
Udara Bersih & 4 & 0 & 2 & 33 & 7 & A & I \\
Fasilitas Halte & 0 & 0 & 0 & 43 & 5 & I & I \\
Fasilitas Terminal & 0 & 0 & 1 & 44 & 3 & I & I \\
Fasilitas Toilet & 0 & 0 & 1 & 41 & 7 & I & I \\
Ketepatan Waktu & 4 & 0 & 8 & 36 & 1 & M & I \\
Perilaku Sopir & 1 & 0 & 22 & 26 & 1 & M & M \\
Perilaku Kondektur & 1 & 14 & 8 & 25 & 1 & &
\end{tabular}

Dari Tabel 2, terlihat bahwa pada perhitungan dengan Kano Tradisional yang sebelumnya belum menggunakan Fuzzy, hasil perhitunganya menyatakan Indifferent untuk semua atribut. Sedangkan untuk pengembangannya, yaitu dengan penerapan Fuzzy, hasilnya berbeda. Dimana untuk atribut Keamanan, Ongkos/ Tarif, Tempat Duduk, dan Udara Bersih yang tadinya Indifferent menjadi Attractive. Dan atribut Kebersihan, Ketepatan Waktu, Perilaku Sopir, dan Perilaku Kondektur juga berubah, dari Indifferent menjadi Must Be.

\section{Customer Satisfaction Coefficient}

Customer Satisfaction Coefficient (CS coefficient) menyatakan tingkat kepuasan customer dapat ditingkatkan jika kriteria yang diberikan produk sesuai dengan kebutuhan pengguna. CS coefficient ini mengindikasikan seberapa kuat fitur layanan dapat mempengaruhi tingkat kepuasan ataupun ketidakpuasan dari customer. Perhitungan tingkat kepuasan dan ketidakpuasan digunakan rumus sebagai berikut:

Satisfaction index $(\mathrm{SI})=\frac{(\mathrm{A}+\mathrm{O})}{(\mathrm{A}+\mathrm{O}+\mathrm{M}+\mathrm{I})}$

Dissatisfaction index $(D I)=-\frac{(\mathrm{M}+\mathrm{O})}{(\mathrm{A}+\mathrm{O}+\mathrm{M}+\mathrm{I})}$ 
Prihono \& Yunia Dwie Murcahyanie: Pengembangan Model QFD Berbasis Fuzzy Kano untuk Jasa Layanan Transportasi Bagi Disabilitas

Tabel 3 Customer Satisfaction Coefficient untuk Bus Penyandang Cacat

\begin{tabular}{lcccccccccc}
\hline \multicolumn{1}{c}{ CUSTOMER } & A & O & M & I & R & Q & KANO CATEGORY & SI & DI \\
\hline Keamanan & 12 & 1 & 0 & 12 & 3 & 2 & A & 0.220 & 0.0 \\
Ongkos/Tarip & 9 & 1 & 0 & 19 & 1 & 0 & A & 0.200 & -0.1 \\
Tempat Duduk & 5 & 1 & 0 & 18 & 3 & 3 & A & 0.140 & 0.0 \\
Kebersihan & 1 & 3 & 5 & 15 & 5 & 1 & M & 0.060 & -0.2 \\
Udara Bersih & 3 & 1 & 0 & 17 & 6 & 3 & A & 0.080 & 0.0 \\
Fasilitas Halte & 1 & 0 & 0 & 24 & 4 & 1 & I & 0.000 & 0.0 \\
Fasilitas Terminal & 0 & 0 & 1 & 27 & 2 & 0 & I & 0.000 & 0.0 \\
Fasilitas Toilet & 0 & 0 & 0 & 21 & 8 & 1 & I & 0.000 & 0.0 \\
Ketepatan Waktu & 2 & 1 & 5 & 20 & 1 & 1 & M & 0.080 & -0.2 \\
Perilaku Sopir & 3 & 1 & 5 & 19 & 1 & 1 & M & 0.020 & -0.4 \\
Perilaku & 2 & 2 & 3 & 20 & 2 & 1 & 0.300 & -0.4 \\
Kondektur & & & & & & & & & \\
\hline
\end{tabular}

Tanda minus diletakkan didepan hasil CS coefficient ketidakpuasan, untuk menunjukkan pengaruh negatif pada tingkat kepuasan pengguna jika kriteria tersebut tidak dipenuhi. Nilai positif dari $C S$ coefficient dalam range $0-1$, semakin mendekati nilai 1 , maka semakin tinggi pengaruh kriteria tersebut pada kepuasan pengguna. Dari Tabel 3 didapatkan bahwa atribut keamanan memiliki nilai tertinggi dalam yang mempengaruhi kepuasan konsumen bus penyandang cacat.

\section{Analisis House Of Quality Analisis tingkat kepentingan (What)}

Tingkat kepentingan atribut yang dipentingkan oleh pelanggan dapat dilihat pada Tabel 4 untuk bus penyandang cacat.

Tabel 4 Nilai rata-rata tingkat kepentingan atribut bus penyandang cacat

\begin{tabular}{lcc}
\hline \multicolumn{1}{c}{ CUST. REQ. } & $\begin{array}{c}\text { SKALA } \\
\text { KEPENTINGAN }\end{array}$ & URUTAN KEPENTINGAN \\
\hline Keamanan & 4.70 & 3 \\
Ongkos/Tarip & 4.65 & 5 \\
Tempat Duduk & 4.67 & 4 \\
Kebersihan & 4.78 & 1 \\
Udara Bersih & 4.77 & 2 \\
Fasilitas Halte & 3.87 & 9 \\
Fasilitas Terminal & 3.76 & 11 \\
Fasilitas Toilet & 3.77 & 10 \\
Ketepatan Waktu & 4.00 & 8 \\
Perilaku Sopir & 4.10 & 7 \\
Perilaku Kondektur & 4.13 & 6 \\
\hline
\end{tabular}

Dari Tabel 3, terlihat bahwa konsumen sangat memperhatikan bahwa kebersihan bus sangat diperhatikan oleh konsumen dalam hal ini penumpang bus penyandang cacat.

\section{Target Value}

Target Value/sasaran yang hendak dicapai, dengan mempertimbangkan kemampuan layanan transportasi lain dan kemampuan yang dimiliki pelaku penyedia jasa transportasi. Hal ini bisa dilakukan dengan membandingkannya. Target value ditetapkan dengan mencari nilai terbesar. Dengan pertimbangan tersebut, hasil perhitungan setiap atribut dilihat dari Tabel 4. 
Tabel 4 Target Value untuk Bus Penyandang Cacat.

\begin{tabular}{clccc}
\hline No & \multicolumn{1}{c}{ Atribut } & $\begin{array}{c}\text { Layanan Bis Kota Patas } \\
\text { Surabaya }\end{array}$ & $\begin{array}{c}\text { Layanan Bis } \\
\text { Trans Jakarta }\end{array}$ & Target Value \\
\hline 1 & Keamanan & 4.85 & 4.95 & 4.95 \\
2 & Ongkos/Tarip & 4.95 & 4.65 & 4.95 \\
3 & Tempat Duduk & 4.87 & 4.44 & 4.87 \\
4 & Kebersihan & 3.43 & 3.95 & 4.78 \\
5 & Udara Bersih (AC) & 4.55 & 4.85 & 4.85 \\
6 & Fasilitas Halte & 2.34 & 3.85 & 3.87 \\
7 & Fasilitas Terminal & 2.28 & 3.43 & 3.76 \\
8 & Fasilitas Toilet & 2.31 & 2.85 & 3.77 \\
9 & Ketepatan Waktu & 3.25 & 3.85 & 4.00 \\
10 & Perilaku Sopir & 3.28 & 4.34 & 4.34 \\
11 & Perilaku Kondektur & 3.35 & 4.25 & 4.25 \\
\hline
\end{tabular}

Dari Tabel 4 bisa dilihat bahwa fasilitas halte yang perlu diperhatikan, karena akses penumpang penyandang cacat mengalami banyak kesulitan. Sehingga campur tangan pemerintah dalam hal ini Dinas Perhubungan yang berfungsi sebagai penyedia fasilitas halte perlu memperhatikan kebutuhan-kebutuhan penyandang cacat.

penumpang

\section{Analisis Improvement Rate}

Improvement rate atau rasio perbaikan merupakan suatu ukuran seberapa besar usaha yang dilakukan untuk meningkatkan kualitas.

Tabel 5 Improvement Ratio untuk bus Penyandang Cacat

\begin{tabular}{lcc}
\hline \multicolumn{1}{c}{ Atribut } & Target Value & Improvement Rate \\
\hline Keamanan & 4.95 & 1.05 \\
Ongkos/Tarip & 4.95 & 1.06 \\
Tempat Duduk & 4.87 & 1.04 \\
Kebersihan & 4.78 & 1.00 \\
Udara Bersih (AC) & 4.85 & 1.02 \\
Fasilitas Halte & 3.87 & 1.00 \\
Fasilitas Terminal & 3.76 & 1.00 \\
Fasilitas Toilet & 3.77 & 1.00 \\
Ketepatan Waktu & 4.00 & 1.00 \\
Perilaku Sopir & 4.34 & 1.06 \\
Perilaku Kondektur & 4.25 & 1.03 \\
\hline
\end{tabular}

Dalam Tabel 5, bisa dilihat bahwa pemenuhan ongkos/tarip merupakan atribut yang paling sulit untuk dipenuhi. Hal ini dikarenakan atribut ini merupakan atribut yang penentuannya seiring dengan pemenuhan atribut tersebut. Serta penentua ongkos/tarip juga ada aturan-aturan dari pemerintah.

\footnotetext{
Analisis Relative Importance Index Relative Imp. Index $=(1+m)^{k} x \mathrm{IR}_{0}$ Dimana:

$m=\max (|\mathrm{SI}|,|\mathrm{DI}|) ; \mathrm{IR}_{0}=$ traditional improvement ratio $; \mathrm{k}=$ Fuzzy Kano Category $(\mathrm{I}=0 ; \mathrm{M}=0,5 ; \mathrm{O}=1 ; \mathrm{A}=2)$ Adapun prioritas atribut-atribut layanan yang diharapkan konsumen seperti ditunjukkan pada Tabel 6 untuk bis penyandang cacat.
} 
Tabel 6 Relative Importance Index bus penumpang umum

\begin{tabular}{|c|c|c|c|}
\hline No & Atribut & RII & Prioritas \\
\hline 1 & Keamanan & 6.76 & 1 \\
\hline 2 & Ongkos/Tarip & 6.22 & 2 \\
\hline 3 & Tempat Duduk & 5.71 & 3 \\
\hline 4 & Kebersihan & 1.82 & 7 \\
\hline 5 & Udara Bersih (AC) & 5.13 & 4 \\
\hline 6 & Fasilitas Halte & 1.00 & 11 \\
\hline 7 & Fasilitas Terminal & 1.03 & 9 \\
\hline 8 & Fasilitas Toilet & 1.03 & 10 \\
\hline 9 & Ketepatan Waktu & 1.78 & 8 \\
\hline 10 & Perilaku Sopir & 2.17 & 6 \\
\hline 11 & Perilaku Kondektur & 2.29 & 5 \\
\hline
\end{tabular}

Tabel 6 menunjukkan bahwa faktor keamanan merupakan atribut layanan yang paling diharapkan konsumen bus penyandang cacat.

\section{Analisis Weight Factor}

Langkah berikutnya adalah mencari pembobotan dari masing-masing atribut dari voice of customer. Hal ini dilakukan untuk megetahui besarnya hubungan voice of customer didalam mempengaruhi perhitungan untuk mencari prioritas perbaikan layanan.

Tabel 7 Weight Factor bus penyandang cacat

\begin{tabular}{clcc}
\hline No & \multicolumn{1}{c}{ Atribut } & Weight & Prosentase \\
\hline 1 & Keamanan & 7.12 & 19.67 \\
2 & Ongkos/Tarip & 6.62 & 18.28 \\
3 & Tempat Duduk & 5.95 & 16.43 \\
4 & Kebersihan & 1.82 & 5.02 \\
5 & Udara Bersih (AC) & 5.21 & 14.39 \\
6 & Fasilitas Halte & 1.00 & 2.76 \\
7 & Fasilitas Terminal & 1.03 & 2.84 \\
8 & Fasilitas Toilet & 1.03 & 2.84 \\
9 & Ketepatan Waktu & 1.78 & 4.91 \\
10 & Perilaku Sopir & 2.42 & 6.69 \\
11 & Perilaku Kondektur & 2.23 & 6.16 \\
\hline
\end{tabular}

Didalam Tabel 7, nilai prosentase yang terbesar masih terdapat pada atribut Keamanan. Sehingga atribut Keamanan merupakan atribut yang paling berpengaruh

didalam mencari prioritas perbaikan layanan yang dikembangkan.

\section{Analisis Respon Teknis}

Untuk memenuhi kebutuhan layanan pengguna bus yang didapat dari hasil kuisioner, maka timbullah respon teknis yang dicari untuk menjawab kebutuhan tersebut, agar bisa lebih meningkatkan kepuasan pengguna bus. Respon teknis dengan nilai kontribusi paling besar adalah respon teknis yang diprioritaskan untuk dilaksanakan. 
Tabel 8 Prioritas repon teknis bus penyandang cacat

\begin{tabular}{clccc}
\hline No & \multicolumn{1}{c}{ Atribut } & Score & Prosentase & Prioritas \\
\hline 1 & Kecukupan waktu naik/turun bis & 334 & 7,34 & 3 \\
2 & Kelayakan Bus & 248 & 5,46 & 8 \\
3 & Karcis Berlangganan & 155 & 3,41 & 15 \\
4 & Kepastian Tarif & 245 & 5,39 & 9 \\
5 & Kelebihan ongkos & 220 & 4,84 & 12 \\
6 & Penggolongan tarip & 236 & 5,20 & 10 \\
7 & Ketersediaan tempat duduk & 257 & 5,66 & 7 \\
8 & Tersediannya Tempat sampah & 136 & 2,98 & 17 \\
9 & Tersediannya AC & 214 & 4,71 & 13 \\
10 & Pengharum ruangan & 170 & 3,74 & 14 \\
11 & Bebas pedagang asongan, pengemis, pengamen, asap rokok & 273 & 6,00 & 6 \\
12 & Dekat jembatan penyebrangan & 282 & 6,21 & 5 \\
13 & Informasi dan pengaduan di Halte & 388 & 8,52 & 1 \\
14 & Informasi dan Pengaduan di Terminal & 372 & 8,19 & 2 \\
15 & ketersediaan air dan tisu & 96,3 & 2,12 & 19 \\
16 & Kecukupan bilik & 39,1 & 0,86 & 21 \\
17 & Disiplin waktu & 154 & 3,38 & 16 \\
18 & Tidak ugal-ugalan & 124 & 2,73 & 18 \\
19 & Ramah dan sopan & 80,5 & 1,77 & 20 \\
20 & Komunikative & 227 & 4,99 & 11 \\
21 & Informative & 296 & 6,50 & 4 \\
\hline
\end{tabular}

Layanan transportasi bus untuk penyandang cacat berdasarkan perhitungan dari house of quality mengutamakan/ memprioritaskan: informasi dan pengaduan di tempat pemberhentian/ halte, kecukupan waktu untuk naik dan turun dari bus, serta kondektur yang informatif.

\section{KESIMPULAN}

Kesimpulan yang dapat diambil dari pengolahan dan analisa yang telah dilakukan adalah sebagai berikut :

a. Penerapan metode fuzzy-KANO dapat digunakan menjadi solusi alternatif dalam mengurangi ambiquous (kerancuan) hasil kategori KANO. Hal ini menandakan bahwa KANO masih belum bisa sepenuhnya mengurangi subyektivitas dari kuisioner yang dikembangkan.

b. Voice of Customer (what) yang dihasilkan kuisioner setelah dihitung dengan QFD dihasilkan bahwa prioritas tertinggi untuk bus penyandang cacat adalah atribut keamanan yaitu sebesar 19,67 .

c. Dengan membuat House of Quality didapatkan nilai bobot untuk setiap respon teknis (how). Masing-masing atribut dinilai berdasarkan bobot respon teknis (how) dan menghasilkan skor atau ranking. Nilai tertinggi pada atribut informasi dan pengaduan di Halte, dengan skor 8,53. Namun untuk atribut ini penyedia layanan transportasi mempunyai kesulitan untuk mewujudkannya. Untuk itu, hal yang memungkinkan untuk bisa dibenahi penyedia layanan transportasi yaitu dengan atribut penyediaan tempat duduk, dimana mempunyai skor 5,66.

\section{Ucapan Terima Kasih}

Penulis mengucapkan terima kasih kepada Universitas PGRI Adi Buana Surabaya, Kementrian Riset Teknologi dan Pendidikan Tinggi, serta Dinas Perhubungan Kota Surabaya. 


\section{DAFTAR PUSTAKA}

Anita Susanti dan RAA Soemitro (2006). "Analisa Persepsi Penumpang Terhadap Tingkat Kinerja KA Komuter Surabaya-Sidoarjo", Prosiding Seminar Nasional Manajemen Teknologi IV, Program Studi MMT-ITS, Surabaya 5 Agustus 2006.

Bevilacqua, M. Ciarapica, F, E. dan Giacchetta, G. (2006). "A Fuzzy-QFD Approach to Supplier Selection”. Journal of Purchasing \& Supply Management,Vol.12, Pages 1427.

Blanco Sebastian (2008), Safe And Green: Mexico City Offers Bus For Woman Only, Http://At.Atwola.Com, Dikunjungi Bulan 24 Januari 2008 Pukul 20:14wib.

Ciptomulyono, U. (1996), "Model Fuzzy Goal Programming Untuk Perencanaan Produksi Terpadu", IPTEK, Vol. November, Hal: 116-127.

Cohen, Lou (1995), Quality Function Deployment, How To Make QFD Work For You, Addison-Wesley Publishing Company, Mass.

Jatmiko Murdiono (2006). "Persepsi Konsumen Terhadap Pelayanan "Busway" Trans Jakarta", Jurnal Ekubank, Vol. 3, Pages 12-17.

Kano, N., Seraku, K., Takahashi, F., dan Tsuji, S. (1984). "Attractive Quality And Must-Be Quality", The Journal of the Japanese Society for Quality Control, Vol.14(2), Pages $39-48$.

Kotler, Philip (2000). Marketing Management, Edisi Indonesia, PT Indeks. Jakarta.

Kusumadewi, S. (2004). Aplikasi Logika Fuzzy untuk Pendukung Keputusan, Graha Ilmu, Yogyakarta.

Lee,Y., Sheu,L., dan Tsou,Y. (2008). "Quality Function Deployment Implementation Based On Fuzzy Kano Model: An Application In PLM System”, Computers \& Industrial Engineering , Doi:10.1016/j.cie.2007.11.014.

Martha J. Smith (2008). "Addressing The Security Needs Of Women Passengers On Public Transport", Security Journal, Vol. 21, Pages 117 - 133.

Meng Zhang, Quanxin Sun, Jinchuan Chen dan Jifu Guo (2008). "Travel Behavior Analysis Of The Females In Beijing", Journal Of Transportation Systems Engineering And Information Technology. Vol. 8, Issue 2, April 2008, Pages 19-26.

Prihono (2012), "Desain Layanan Kendaraan Umum untuk Wanita Berbasis Fuzzy-Kano Quality Function Deployment", Jurnal Teknik dan Manajemen Industri, Vol.7, No. 1, Page : 44-54.

Ramaswamy Rohit (1996). Design And Management Of Service Processes” Keeping Customer For Life", Addison-Wesley Publishing Company,Inc.

Sauerwein, E., Bailom, F., Matzler, K., Hinterhuber, H. (1996), The Kano Model : How To Delight Your Customers, Proceeding of International Working Seminar on Production Economics, Pages. 313-327.

Suhartini. (2011). "Pendekatan Fuzzy-QFD dalam Pemilihan Supllier", Jurnal Matrik. Vol.6. No. 1. Page : 1-10.

Temponi C.,Yen J. dan Tiao W.A. (1999). "House of Quality: A fuzzy Logic-Based Requirement Analysis", European Journal of Operational Research 117, 340-354.

Tjiptono, Fandy (2005). Manajemen Jasa, Edisi Kedua, Andy Offset, Yogyakarta. 